\title{
The Main Effects of MiFID on European Capital Markets and European Integration
}

\author{
Athanasios G. Panagopoulos ${ }^{1}$, Thomas Chatzigagios ${ }^{1} \&$ Ioannis Dokas ${ }^{2}$ \\ ${ }^{1}$ University of Macedonia, Faculty of Accounting and Finance, Thessaloniki, Greece \\ ${ }^{2}$ National and Kapodistrian University of Athens, Department of Economics, Athens, Greece \\ Correspondence: Athanasios G. Panagopoulos, PhD candidate, University of Macedonia, Faculty of Accounting and \\ Finance, 64 Anatolikis Romilias str., Glyfada, Attica, GR165 62, Greece. Tel: 30-6944-719-671. E-mail: \\ thpanag@uom.edu.gr
}

Received: June 14, 2015

Accepted: September 4, 2015

Online Published: September 7, 2015

doi:10.5430/ijba.v6n5p52

URL: http://dx.doi.org/10.5430/ijba.v6n5p52

\begin{abstract}
This paper aims the research whether the application of European Directive MiFID, had any significant effects on the European Capital Markets and the progress of the European Integration. This new regulation specifies the tasks and responsibilities of the supervisory authorities of the Member State of origin and the host Member State, in order to enhance the certainty of effectiveness of cross border transactions supervision and to reduce the risk of imposing unnecessary legal reforms from the host Member State on investment firms which perform cross border transactions. The research work focuses on the existing regulation and the literature for MiFID and European Integration and on whether the set of its regulation reforms could aim (or not) in contributing to excess of the European Capital markets and Institutions as long as the financial integration of EU. The reasons for the different degrees of integration and liberalization, is essentially related to financial structures. Under this reasoning, we have examined the effects on European Financial Market Integration concerning banks, Stock Exchanges and financial intermediaries and we have concluded, among others, that the aligning of the national regulatory approaches to a common European regulatory system is quite necessary. We finally conclude that MiFID will contribute to reduce problems at country level as the previous experience of the Investment Services Directive, where the European investments and economies of Member States were based mainly on the level of "country" and not of the "sector".
\end{abstract}

Keywords: MiFID, capital markets, European integration, financial markets

\section{Introduction}

The Markets in Financial Instruments Directive 2004/39/EC (known as "MiFID") as subsequently amended, is the most recent of a series of legislative changes introduced by the European Commission in implementing the Financial Services Action Plan (FSAP) and furthermore a process of harmonization of European capital markets, which continues for over a decade. EU Member States committed to create a more efficient and integrated financial services market with the target of "the most competitive and dynamic knowledge-based economy in the world", capable of maintaining economic growth and employment as well as social cohesion (Lisbon meeting of the European Council, March 2000).

The objective of creating an integrated European market for financial services has been incorporated into the FSAP ratified in 2000 by the European Council in Lisbon. The FSAP provides guidelines and consists a framework with regulatory measures. Some of these measures were taken in the pre-FSAP period, including the original Investment Services Directive (ISD) (Note 1). The ISD was incorporated into national legislative systems and introduced the European Passport, enabling Investment Services Companies (ISC) to provide investment services in the Member States, allowing cross-border private equity European Stock Exchanges and lowered the national regulatory barriers (Andenas \& Kenyon-Slade, 1993). As part of the FSAP, the ISD was set under review, resulting in the adoption of the draft directive ISD-2, which was the precursor of MiFID), which in turn adopted by the European Council on April 2004.

Under the next major EU directive on market abuse (2003/6/EC), the Market Abuse Directive (MAD), which was also incorporated in national legislative systems, the FSAP objectives were also implemented, in terms of promoting 
the integration of European financial markets and reducing the complexity and confusion regarding the rules on market manipulation. In addition, the Directives' interpretation limited the doubts and the consequent risk of differences in the implementation and enforcement of FSAP provisions, across EU. But, there is need to consider seriously the question of how a control of "intent" can be incorporated in the legislation and a defence of lack of intent to manipulate the market.

However, MiFID, essentially, aims at enhancing the transparency of European stock markets and to ensure the protection of interests of investors (particularly, retail investors). At the same time, MiFID aims to increase market efficiency, enabling investment firms (ISCs) to benefit from the business opportunities that arise by using the right to extend their business, across the European territory based on the legislation governing their domestic market.

With the adoption in the legislative systems of the Member States, MiFID intends to achieve a set of objectives. Thus, under MiFID, the transparency regarding the depth of liquidity in all alternative venues executing securities' transactions, is increasing, including transactions executed: on regulated markets (Stock Exchanges), on non-regulated markets (bilaterally traded as OTC derivatives), multilateral trading facilities (MTFs) and within the investment firms (ISC) towards their own portfolio (internalized) (Moloney, 2002 \& Murphy, 2013). Additionally, there is an increase of the protection of retail investors, through the regulation of a broad range of investment services, from the execution of orders, up to providing investment advice and analysis in stock markets, where specific order management requirements were introduced in order to achieve optimum execution of client orders (best execution). The competition between regulated markets (Stock Exchanges) and MTFs is enhanced and the obstacles for the connection of ISCs with alternative execution venues for transactions throughout Europe are removed. The emphasis and clarity are strengthened regarding the obligation of the investment firms to undertake appropriate measures to avoid any internal conflicts of interest. Finally, the level of disclosure of information to retail investors increases, including greater transparency in relation to the transaction costs.

\section{Literature Review and Methodology of Research}

There is a clear evidence of the "positive" influence of gradual protection of the European Capital Markets, under a proper institutional framework for the market manipulation (during 2001-2006). This means that the increased trading activity of the European markets, its maturity, its openness and its correlation with international markets and developments, gave no signs of increased manipulation (taking into account the development of Supervisory Trading Control Systems - STCS, which can discover such kind of transactions). The harmonization of EU legislation proved successful for this Directive (Panagopoulos, 2007), from this point of view.

The research continues with a discussion of the main developments in European capital markets and European Integration, over the past decade and reviews the effects of the ISD. We next rehearse the key points of MiFID and discuss the issues raised by its implementation for the various markets affected. While numerous papers have already been published on how to prepare for MiFID, there has been much less consistent analysis of its impact on the market and the industry (Casey \& Lannoo, 2009).

We have also noticed that few Investment Firms (IFs) doubt about the overall positive impact of MiFID. However, there are also high costs due to the fragmentation of the trading environment, in particular in terms of liquidity and transaction costs, even though the cost per transaction has gone down drastically. Specifically, the liquidity fragmentation increased the risk of market impact and pushed down the average size of trades, thus the number of transactions skyrocketed after the implementation of the Directive (Greuning \& Bratanovic, 2003). However, these issues may be explained by the deterioration that IFs see in the quality of trading data, which in their view, have not kept up with the evolution in the market structure (Valiente \& Assi, 2011).

We have also examined the way of how MiFID was instituted. Indeed, MiFID was applied, based on the process of the four stages of the Lamfalussy Report (Schaub, 2005). This was involved an implementation approach that begun with a European directive by the European Council (I), progressing to more detailed and technical clarification of certain provisions of the Directive (II). Then, continues with the cooperation between national regulator authorities for the single application of rules (III) and ends with the incorporation of the Directive into the national legislative systems of Member States defining the functioning of their markets (IV).

Briefly, the Lamfalussy Process includes:

- Level 1: Legislation and guidelines - European Council,

- Level 2: Technical implementation guidelines - E.S.C. (Note 2) and E.S.M.A. (Note 3),

- Level 3: Rules of local behaviour of ISC - E.S.M.A. and national regulatory authorities, 
- Level 4: Rules enforcement by Member States, as well as cooperation between supervisor authorities.

The European Commission has published a series of working documents that clarify many articles of MiFID and are still being subject to discussion, even now days, and under possible amendment. These texts are related to:

- the methods and procedures for the submission of financial transaction reports (ESC/7/2005),

- the organizational requirements and the management of conflicts of interest (ESC/17/2005),

- the transparency and acceptance for the trading (ESC/20/2005),

- the behavioural rules, and the rules for the best orders handling and execution (ESC/23/2005).

The deadline for the adoption in the legislative systems of the Member States was November 2007. The typical transition time for a European directive in national legislation is two years from its adoption. Nevertheless, even this date does not leave sufficient time to the ISCs, investment firms and other market participants to realize the effects of MiFID in the Capital Markets and on their selves for performing the necessary changes. ISCs and Investment firms must undertake immediately initial measures for assessment and program development for MiFID's requirements.

Certain rules for the ISCs and investment firms are provided, relating to the following (Mertzanis, 2007). These rules broadened the business area for new financial instruments and services, as well as reduced the totally required capitals and institutionalized the Over-The-Counter (OTC) markets:

- The Investment firms (ISCs) which execute client transactions using the financial instruments provided by MiFID (Directive 2004/39/EC of the European Parliament, Annex I, Section C, 2004) should do so through a company properly licensed by a competent authority within Europe. IFs do recognise the positive role of MiFID in promoting competition, transparency and investments in IT infrastructures (also for trading venues). They do not agree on the quality of trading data and almost half of responding IFs declare that there have been no changes or negative changes, in the quality of data with the introduction of MiFID (Valiente \& Assi, 2011).

- The Investment Firms are allowed to enter in trade derivatives contracts on commodities, credit, interest rates, climatic variables and pollutant emissions (Hudson, 2002).

- The range of the investment services, the provision of which requires authorization to provide them, is widened (Directive 2004/39/EC of the European Parliament, Annex I, Section B, 2004).

- The Investment Firms can install new European branches without obligation to fulfil additional regulatory requirements by the regulatory authority of the host-Member State.

- The new regulation specify further, the duties and responsibilities of the supervisory authorities of the Member State of origin and the host Member State, resulting in certainty enhancement as to the effectiveness of supervision of cross border transactions and reducing the risk of imposing unnecessary regulations from the host Member State on the Investment firms which perform cross border transactions.

- Investment Firm's transactions on commodities (for own account) may not be subjected to further regulation.

Following on from the EU Commission's December 2010 consultation to reform the MiFID, the Commission published its legislative proposals, which took the form of a revised Directive (MiFID II, 2014/65/EU 2014) (Note 4), with the following changes:

- Commodity derivatives: The revisions to MiFID are adapting some elements of the existing directive and introducing a new regime of position limits and position reporting

- Transparency: The existing pre and post trade transparency regime in MIFID applies only to shares admitted to trading on a regulated market. That regime is being revised and a regime will be applied to non-equities.

- High frequency trading: The revised MiFID will introduce specific provisions designed to ensure that high frequency trading (HFT) (Note 5) does not have an adverse effect on market quality or integrity.

- Market Structure: The revisions to market structure are designed to produce comprehensive regulation of secondary trading that is fair, efficient and safe.

- Organizational requirements: The revised MiFID will introduce expanded requirements in respect of the management of firms, explicit organizational and conduct requirements relating to product governance arrangements and a prohibition on title transfer collateral agreements involving retail clients. 
- Trade reporting: The provisions in the revised legislation on trade reporting are designed to resolve problems with the quality and availability of data that have been observed since the original directive was introduced.

- Conduct of business rules: The revised legislation seeks to enhance the levels of protection granted to different categories of clients.

- Transaction reporting: The scope of the transaction reporting obligation is being extended, the scope of the reports is being enhanced and an EU-wide system of Approved Reporting Mechanisms (ARMs) is being introduced.

A new framework will improve conditions for competition in the trading and clearing of financial instruments. This is essential for the integration of efficient and safe EU capital markets. For this purpose, MiFID II establishes a harmonised EU regime for non-discriminatory access to trading venues and central counterparties (CCPs). Smaller trading venues and newly established CCPs will benefit from optional transition periods. The non-discriminatory access regime will also apply to benchmarks for trading and clearing purposes. Transitional rules will ensure the smooth application of these provisions (European Commission, Press Release Database, 15/4/2014).

\section{Analysis of Current Developments and Effects on European Capital Markets and the European Integration}

\subsection{European Capital Markets}

MiFID defines management principles for internal conflicts of interests regarding the ISCs, as well as segregation requirements of their business duties. Investment firms should have an independent internal audit department to comply to legislation and provide adequate participation of senior executives and accountability of those in the compliance process. The remuneration of staff of the internal audit department should not compromise its independence, (ie. the granted bonuses should not be linked to the financial performance of companies). Any material conflict of interest must be communicated to clients and to the supervisory authority. Investment firms must establish and keep a 'conflicts of interest management' policy and maintain effective barriers to information leakage (eg Chinese Walls). In case that an Investment Firm produces and distributes analysis reports, additional specific requirements are applied to ensure that the company and individual analysts don't face any conflicts of interests.

Regarding investor issues, MiFID intervenes as follows:

- establishes a common European framework, classifying them as either "retail investors" or as "professional investors" or as "eligible counterparties" which is a special category referred to those who need less protection than the other customers/investors.

- a significant part of MiFID aims to protect the retail investor, establishing obligations of Investment Firms towards their clients regarding investment advice provisions, order execution, trading information disclosure and provision of reports to them.

- establishes the obligation to conduct suitability test to customers before the providing of any investment advice or its portfolio management. The order execution is excluded from the test, only.

- the classification of the eligible counterparties has been clarified with quantified guidelines-instructions and specific disclosure requirements, where a client has been classified as an eligible counterparty.

Regarding issues regarding information disclosed and provided, MiFID intervenes as follows:

- Investment Firms are required to provide their customers with sufficient information and reports on their transactions in a clear and understandable form, including details for the transaction costs.

- Investment firms are required to provide their customers with trade confirmations within one working day from the date of transaction (with the exception of the usual collective investments).

- Investment firms are required to keep their clients' transaction data for at least 5 years and to disclose in a daily basis to the competent supervisory authority, details for the transactions on regulated markets, up to the close of the next day's trading session.

- Investment firms are required to keep records of telephone conversations with clients for one year.

- the information requirements for retained records of submitted transaction reports to customers are growing (these files include transaction execution venue, the execution time, the client's identity, etc.). 
- the trade reporting obligations to customers can be met by the investment firm itself or by an authorized third party, such as an MTF (Note 6) or a regulated market.

- MiFID has clarified that the Internet is a persistent disclosure of information medium.

Regarding the MTFs and Market regulation issues, MiFID intervenes as follows:

- the current trading concentration rule (Note 7) which is in force in many European Member States is abolished, while pre-trade transparency obligations are introduced, enhancing cross-border trade opportunities through conducting MTFs.

- the Investment firms that make internalization of transactions, are defined as Systematic Internalisers (Note 8), with specific stock price reporting obligations.

- Multilateral Trading Facilities - MTFs (ie ECNs, ATSs (Note 9)) are included, as the national Stock Exchanges, in the scope of European legislation.

- the MTFs will be able to use for transactions settlement Central Counterparty Clearing House (CCP) or a Repository, that is based in a different Member State of EU.

Regarding clients' orders management and their best execution issues, MiFID intervenes as follows:

- the obligations of 'best execution' of the order, require that Investment Firms should ensure the best possible execution of client orders, taking into account multiple factors (price, transaction costs, execution transaction speed, possibility of order execution and its clearance) and alternative order transaction venues (Stock Exchanges and MTFs in the European territory) in which they have access.

- Investment firms must maintain an official orders execution policy and be able to prove that they follow this policy.

- Investment firms should be able to demonstrate that their clients' orders have been executed in accordance with their policy.

- the removal of the 'trade concentration rule' and its impact on the creation of alternative sources of liquidity concentration will result a considerable complexity in defining and fulfilling the orders' best execution obligations.

- Investment firms should realize the transaction costs analysis of the orders they execute, in order to be able to supervise the excellent (best) execution of them.

- it is established specific rules concerning the collection of client orders and the setting of order execution priorities based on time of its reception.

- the Investment firms which receives limited orders which can not be immediately executed, they must disclose them in order to increase their execution possibility.

Regarding the issue of 'pre-trade' and 'post-trade' transparency, MiFID intervenes as follows:

- MiFID defines the activities of the Investment Firms, which are classified as 'Systematic Internalisers' (ie. Investment firm which, in the frames of orders execution and/or management of client portfolios, they cross and execute orders, internally, against the positions of their own securities account). These firms must announce fixed stock prices, which are recognized in regulated market venues on a regular and continuous basis during normal trading hours. These prices must be affordable to the market at a reasonable commercial basis.

- These prices must be treated as constant for transactions up to specific level.

- The report of 'post-trade' information by Investment Firms includes the obligation to disclose this kind of information (as close as possible to the real time) in a reasonable commercial basis.

MiFID required that Investment Firms have to adopt immediate adjustment measures, in order to satisfy all necessary requirements, until the effective date (November 2007). The prompt assessment and the adaptation planning require a wide representation from all company's departments: business development, operations, IT department and the internal audit department. It is obvious, that the successful adaptation to MiFID's requirements, demands notification and decision making by all these departments, in order to realize the extended MiFID's effects.

This assessment will allow Investment Firms to take advantage of the opportunities, to influence the implementation of new regulations on local market practices, as well as to work together with the suppliers of technology systems, in 
order to understand the requirements. Moreover, this leaves to Investment Firms an important timeframe for programming and maximizing the partnership benefits with other initiatives, so that the compliance to MiFID to be achieved at a minimum cost.

\subsection{European Integration}

European financial markets, as well as Good markets, are more integrated and liberalized in the territories of Member States rather than in their cross-border relations. The reasons for the different degrees of integration and liberalization, is essentially related to financial structures. Although, the partial release of the European financial markets leads to high costs for consumers and producers of financial services, primarily due to smaller Member States of a monetary union, many economists believe that a monetary union will eventually improve the release of the European Financial Markets.

This happens because, since the release of European Financial Markets, the prices of financial goods from different regions, were equalized (except the difference in transactional costs), while the financial intermediaries in different regions have access to make transactions, also, from different regions and additionally they have the opportunity to decide to borrow, to invest and to hedge the risk. Essentially, the effect is the increase of the availability and diversity, which will bring the independence of investment decisions on savings, as well as, the capital position will be adjusted smoothly and will hedge any current imbalances.

Under this reasoning, MiFID will contribute to the integration of the European capital markets at the point where its implementation will induce the normalization of the diverse transactional costs, through increased transparency trading procedures, releasing of activities, as well as the upgrading of the level and the diversification of funding, mainly through the removal of obstacles to cross-border transactions.

We can sustain, that MiFID will contribute to reduce problems at country level as the previous experience of the Investment Services Directive, where the European investments and economies of Member States were based mainly on the level of "country" and not on the "sector". Besides, IPOs and financing in the EU today, are especially applied at a country level rather than across borders. Therefore, the European financial services market is fragmented and the Investment Firms are companies with restricted administrations and only recently, a mobility in mergers between these companies and Stock Exchanges is noted, but this is mostly happens inside of the Member States and not in between Member States. Also, the clearing and settlement are more fragmented procedures and therefore costly, enough.

The effectiveness of MiFID on eliminating the "phenomenon" of financial goods transaction, mainly at a country level and also the realization of the advantages of the widespread availability and dispersion, will depend on whether the "after-the-MiFID" European consumers of financial services will gain:

i) a real option to use licensed financial services with a European passport,

ii) a real improvement of their assets to diversify their goods in the EU and finally,

iii) a real reduction of transaction costs with the best possible execution without any compromise to their adequate protection.

The third stage of the Lamfalussy process for the implementation of MiFID, it is crucial to prevent new restrictions on the financial instruments, giving liquidity to the market, thereby. Additionally, the elimination of "phenomenon" of financial goods transaction, at a country level, will also depend on whether the "after-the-MiFID" European stock brokers will gain:

i) a real freedom of choice of access to markets, and

ii) a freedom to access issuers information.

This access should be a real access to all European clients, to clearing and settlement infrastructures at low cost and to opportunities for innovative responses for diversifying the demands of European consumers.

At the point where the European Stock Exchanges will be able to gain more access to a larger number of investors and financial intermediaries and achieve better costs and more efficient clearing and settlement services, facilitating, with this way, the use of diversified securities for transactions across the market, someone would expect the improvement and the reduction of the unfairness at "country" level of the transactions. This possible improvement also depends mainly on the real opportunities as well as on the response of business: will they prefer the listing of their shares in other organized European markets and see them to be traded on alternative systems at a lower cost? 
The actual impact of MiFID on the average cost of capital in the EU and therefore the liquidity of the market are very important.

It should be underlined that the structural fragmentation of the markets is an obstacle to the efficiency of financial intermediaries, but can serve as a bulwark to a wide spread of a systemic risk. Therefore, the effectiveness of MiFID on reducing the effects due to the structural fragmentation of the market could perhaps be burdened by the cost of increasing the probability of a systemic risk.

MiFID's implementation is expected to broaden the chances of passing the risk to Financial Intermediaries. Additionally, due to the expansion of markets and the diversification of financial instruments, MiFID imposes the existence (even more the creation) of specific administrative and accounting procedures for the investment firms, for grip internal audit mechanisms and for risk management and information systems effective tools. Moreover, it is necessary to ensure the continuity and consistency for the performance of investment services and activities and the use of appropriate infrastructure, resources and procedures.

MiFID introduces the operation of alternative transaction execution venues, as well as the greatest transparency requirements for trading with financial instruments, which are common among different venues. The emphasis on larger and standardized disclosure on transactions information, contributes to reducing the differentiated information. Of course, the internal information is classified as 'market abuse'. However, achieving equivalent information has a cost: the increased homogenization and hence the future reduction of liquidity. Under MiFID, the national regulators respond to the creation of a widened financial market and to Investment Firms' mergers, due to they require all of them to operate under the same regulatory status (same rules, incentives and penalties).

The objectives of MiFID in terms of promoting the European financial markets integration and reducing the complexity and confusion regarding the rules on market manipulation and homogenization of markets in the use of financial instruments, is completely justifiable. In addition, the doubts of Directives' interpretation were limited, as well as the consequent risk of differences in the implementation and the enforcement of its provisions, across the EU.

The EU policy regarding the completion of the single financial market, the Euro and technology, have radically altered the familiar banking and brokerage backdrop. This significant trend is depicted on the cross-border mergers and acquisitions and on the growing competition between the major financial centres, particularly Stock Exchanges.

Following on from the EU Commission's (December 2010) consultation to reform the MiFID, the Commission published its legislative proposals, which took the form of a revised Directive (MiFID II (Note 10)) and a new Regulation (MiFIR), on 20 October 2011. Very broadly, as already said, these proposals represent a comprehensive and profound set of reforms which will lead to a reshaping of the financial markets, the products and services that banks provide and the relationship between banks and their customers.

\section{Research Results, Suggestions and Discussions}

We conclude from our research that, the stability of the European Financial Integration may not increase, dramatically, with the implementation of MiFID. Still remains the regulatory work of the effectively restrain of the systemic risk not only within the EU, but worldwide, which requires an understanding of the connection between the micro-economic risk and the performance of macro-economic fundamentals.

Thus, we sustain that, MiFID as reforming the homogenization of the European financial markets does not take into account the relationship between the micro-economic risks undertaken, as well as the macro-economic performance and restricts its operation within the classical perspective of the Member State. In order to better exploit the benefits of an open post-MiFID European financial system, we have to realize the risks be imposed on society by the independent investors which undertake the risk and by those who undertake a more fair percentage from the social costs. Essentially, this means that in the post-MiFID era, the regulators need to develop effective mechanisms against the financial failure of satisfying the debts of financial firms.

The domination of the regulators should be aligned with the domination of the market. Consequently, the basic regulatory functions - supervision, legislation, information disclosure, authorization and law enforcement - must take place in a very consistent way across the EU.

The single financial market has been completed, mainly in the major capital markets but the retail financial services are still fragmented inside national frames (eg mortgages and consumer credit). These changes bring strategic dilemmas not only for the large financial centres but also for the regional financial centres. The case law of both national courts and the European Court of Justice play an important role for the proper functioning of the capital markets. 
We also suggest that the European Commission should proliferate the discussions between the EU-US for the financial reforms, but also with other countries (Japan, Russia, China, etc.). At the same time, should increase its strong representation in international organizations, through which must speak with one single voice for issues like: the fight against financial crime, money laundering, corruption in the financial sector, business crime, etc.

We consider, that the last, needs collaboration and information exchange even among offshore financial centres. Our conclusion lies on the rationality of the law to prevent and combat money laundering and the reintroduction of sanctions within the framework dictated by sober assessment of the demerits of the act, based on the constitutionally guaranteed in Member States, principle of proportionality.

As another concluding comment, we argue that the support of EU Ministers regarding the powers and resources is quite important at this particular time. The members of the ESMA (Note 11) now are changing attitude, asking the European Commission not to be informed, only, about the preparation of their national legislation, but to be oriented to an everyday effective harmonization of the new regulatory framework, created by the Directives of the Action Plan for Financial Services.

We consider that the alternative is clear: fragmented and inefficient financial markets and/or a patchwork of national liquidity reserves, which will be subjected to diverge and uncoordinated risk management practices, as well as to a higher cost of capital.

We, steadfastly, believe that, the issue at stake is about competition, stability and the integration of EU market infrastructures. Although the vertical integration model of trading and post-trading infrastructures may present advantages in terms of coordination, it may also introduce inefficiencies with respect to competition and price transparency. The introduction of non-discriminatory access requirements in the Regulation on OTC derivatives, central counterparties and trade repositories (under a Directive known as EMIR (Note 12) - European Market Infrastructure Regulation) is a response to these potential negative effects. While EMIR covers only OTC derivatives, MiFID II will cover all financial instruments.

Finally, we have to mention the importance of the Member States political support, in the effort for greater supervisory harmonization, between securities regulators in the European Union. Indeed, during Spring 2006, the ECOFIN accepted the confirmed order to ESMA, to promote the prudential harmonization. The declared support for ESMA's work and the basic list of proposals for further supervisory harmonization, consist an important political step forward for the Member States of the European Union, following the adoption of the Declaration of Stockholm introduced the Lamfalussy process for financial services in March 2001 and created initially CESR (Note 13) (ESMA's predecessor).

In a summary, we would argue from our research, that regarding MiFID, contrary to what some market researchers say, there is no reason to panic. But, the impact and effects of the implementation of MiFID on Investment Firms are real and extensive and in turn, lead to the need of covering the mandatory adjustment requirements. However, MiFID created business opportunities, as it touches many sides of the European financial system and encourage the development of the cross-border supply of investment services. Certainly, after the initial market turmoil, there will be many benefited and harmed Investment Firms. The more timely and properly placed to address the challenges of MiFiD, the greater will be the likelihood of interest and level of benefits, for them.

\section{Concluding Comments and Further Research}

Under this paper, we conducted a research whether the application of European Directive MiFID, had any significant effects on the European Capital Markets and the progress of the European Integration. We studied the existing Directives regulation, as well as, BIS (Note 14) reports, apart from other international literature. We have concluded that the structural segmentation of markets is an obstacle to the efficiency of stock market financial intermediaries, but can serve as a bulwark to a wide spread of systemic risk. Therefore, the effectiveness of MiFID on reducing the effects due to the structural segmentation of the markets, could be probably burdened by the cost increase of the probability of systemic risk. Under this reasoning, we examined the effects on European Financial Market Integration concerning banks, Stock Exchanges and financial intermediaries and we have concluded, among others, that the aligning of the national regulatory approaches to a common European regulatory system is quite necessary.

The aligning of the national regulatory approaches to a common European regulatory system, represents a real challenge, as it entails significant initial costs for the adaptation of the national competent authorities and bodies of the markets. These transitional problems are a challenge for themselves - especially to the extent that they had been concentrated on a brief period (2005-2007). However, concerns about these transitional costs should not obscure the general economic advantages. 
An effective capital business market is a strategically important element in the development of new and innovative businesses, encouraging entrepreneurship, increasing the productivity and maintaining high economic growth rates in Europe. Currently, European venture capital market is much less effective than that of the US market, for example. Therefore, in this area, should be specified the priorities that will lead to new initiatives.

The FSAP has created a legislative framework to allow issuers, investors and financial services providers to make transactions on a pan-European level without undue legal impediments. What matters today, is that we have to ensure, its smooth operation. The economy and markets indicators show that the European financial integration is underway in many sectors: wholesale markets, stock markets and financial market infrastructures, particularly regarding the clearing and settlement of transactions.

The last, improved the conditions for all users of financial services and a "reflective" European market is already beginning to take shape, although many things still need to be done. Thus, the retail distribution sector remains fragmented, while the penetration in some markets is impossible. These barriers should be carefully assessed, particularly on determining whether they are substantial economic barriers to the free movement of capital and financial services, or not. These barriers are, also, restrictions to our research, so additional research is needed on it.

The welcome and the recognition of ESMA efforts, states initially the equivalence of powers between national supervisory authorities and secondly that this harmonization will contribute to a greater investor protection, ensuring that investors will be able to benefit from the same protection when buying investment products across borders.

The design of an adequate regulatory framework is not enough. It needs a daily application of that regulatory framework in a consistent way across Europe, so as the advantages to benefit both investors and market intermediaries.

The strong political endorsement of the efforts of supervisor authorities is important, if we have to achieve the ensuring of an effective communication network between the supervisory authorities of the European Union. This network must adopt innovative communication means to address the cooperation between the supervisory authorities of the home Member State and the host Member country, as well as to strengthen a common supervisory culture. The next political development consequences on European economic issues, is another object, which needs further research.

It is time, to realize that our decision as European Union to respond positively to a request for more security (coming from the other side of the Atlantic), will result to a gradual abandonment of the protection of fundamental rights, as well as, will certainly lead to the increase of a highly typical and ineffective reporting system to the competent authorities, with insignificant disclosures. This will weaken any supervisory role of them.

\section{References}

Andenas, M., \& Kenyon-Slade, S. (1993). Financial Market Regulation and Company Law. Sweet \& Maxwell, London.

Assi, B., \& Valiente, D. (2011). MiFID Implementation in the midst of the Financial Crisis: Results of an ECMI Survey. ECMI Research Report, No.6, Feb 2011, European Capital Markets Institute, Brussels.

Basle Committee on Banking Supervision. (2010, Dec., rev. 2011, June). Basel III: A global regulatory framework for more resilient banks and banking systems. Bank for International Settlements, Basle.

Basle Committee on Banking Supervision. (June 2006). Basle II: International Convergence of Capital Measurement and Capital Standards (revised framework, comprehensive version). Bank for International Settlements, Basle.

BIS (Bank for International Settlements). (2001). Marrying the Macro- and Micro-Prudential Dimensions of Financial Stability. BIS Papers, no.1, Bank for International Settlements, Basle.

Casey, J-P., \& Lannoo, K. (2009). The MiFID Revolution. Cambridge University Press, Cambridge, UK.. http://dx.doi.org/10.1017/CBO9780511770470

Directive 2004/39/EC of the European Parliament and of the Council of 21 April 2004 on markets in financial instruments amending Council Directives 85/611/EEC and 93/6/EEC and Directive 2000/12/EC of the European Parliament and of the Council and repealing Council Directive 93/22/EEC [Official Journal L 145 of 30.4.2004].

Directive 2014/65/EU on Markets in Financial Instruments (MiFID II) [OJ L 173, 12.6.2014, p. 349-496].

Directive 2003/6/EC of the European Parliament and of the Council of 28 January 2003 on insider dealing and market manipulation. Market Abuse Directive - MAD. 
European Commission. (2014). MiFID II: FAQ. Press Release Database, 15/4/2014, Brussels.

England, C. (1991). Governing Banking's Future: Markets vs. Regulation. Kluwer, Boston.

Greuning, van H., \& Brajovic-Bratanovic, S. (2003). Analyzing and Managing Banking Risk: A Framework for Accessing Corporate Governance and Financial Risk. The World Bank, Washington DC. http://dx.doi.org/10.1596/0-8213-5418-3

Hudson, A. (2002). The Law on Financial Derivatives. Sweet \& Maxwell, London.

Mertzanis, H. (2007). The European Directive for the Markets in Financial Instruments 2004/39/EC 9MiFD): Fundamental reforms and adjustment practices of the Investment Services Firms. European Integration and MiFID. Research Study, Feb 2007, Hellenic Capital Market Committee, Athens.

Moloney, N. (2002). EC Securities Regulation. Oxford University Press, Oxford.

Murphy, D. (2013). OTC Derivatives, Bilateral Trading and Central Clearing: An Introduction to Regulatory Policy, Market Impact and Systemic Risk (Global Financial Markets). Global Financial Market Series. http://dx.doi.org/10.1057/9781137293862

Panagopoulos, A. (2007). The harmonization of the EC directives and regulations in the European and Greek Legislation Systems regarding the Market Abuse Directive and the use of Financial Tools. Research paper, Retrieved fromwww.agii.gr/Forum.asp, the Internet site of "Association of Greek Institutional Investors", May 2007. http://www.agii.gr/repository/upload/panagopoulos_sort.pdf

Regulation (EC) No 1060/2009 of the European Parliament and of the Council of 16 September 2009 on "Credit Rating Agencies".

Regulation 600/2014 on Markets in Financial Instruments (MiFIR).

Schaub, A. (2005). The Lamfalussy process four years on. Journal of Financial Regulation and Compliance, 13(2), Emerald Group Publishing Ltd. http://dx.doi.org/10.1108/13581980510621947

\section{Notes}

Note 1. Council Directive 93/22/EEC of 10 May 1993 on investment services in the securities field.

Note 2. European Security Committee

Note 3. European Securities and Markets Authority (E.S.M.A. replaced C.E.S.R. on $1^{\text {st }}$ Jan 2011)

Note 4. Directive 2014/65/EU on Markets in Financial Instruments (MiFID II), as well as, the Regulation 600/2014 on Markets in Financial Instruments (MiFIR)

Note 5. High-frequency trading (HFT) is a primary form of algorithmic trading in finance. Specifically, it is the use of sophisticated technological tools and computer algorithms to rapidly trade securities. HFT uses proprietary trading strategies carried out by computers to move in and out of positions in seconds or fractions of a second. It is estimated that as of 2009 , HFT accounted for $60-73 \%$ of all US equity trading volume, with that number falling to approximately $50 \%$ in 2012. High-frequency traders move in and out of short-term positions at high volumes aiming to capture sometimes a fraction of a cent in profit on every trade. HFT firms do not consume significant amounts of capital, accumulate positions or hold their portfolios overnight.

Note 6. Multilateral Trading Facility. Article 4 (15) of MiFID describes MTF as multilateral system, operated by an investment firm or a market operator, which brings together multiple third-party buying and selling interests in financial instruments - in the system and in accordance with non-discretionary rules - in a way that results in a contract.

Note 7. MiFID eliminated the "concentration rule" formerly prevailed in Europe, that required that stocks be traded through local markets. It paved the way for electronic trading platforms to compete with the established stock exchanges and introduced the concept of a multilateral trading facility (MTF).

Note 8. The "Systematic Internalisers", matches customer orders internally rather than showing these to the market. Systematic internalisers, traditionally called "market makers", are investment firms who could match "buy" and "sell" orders from clients in-house, provided that they conform to certain criteria. Instead of sending orders to a central exchange, banks can match them with other orders on its own book (Financial Times Lexicon).

Note 9. Electronic Communication Network, Alternative Trading Systems 
Note 10. The European Parliament endorsed MiFID II and MiFIR on 15 April 2014, and the Council of the European Union adopted the legislation on 13 May 2014. The MiFID II legislation was published in the Official Journal on 12 June 2014. Both MiFID II and MiFIR entered into force on 2 July 2014 (20 days after publication), and must generally apply within Member States by 3 January 2017.

Note 11. European Securities and Markets Authority

Note 12. European Market Infrastructure Regulation (EMIR) is a European Union regulation designed to increase the stability of the over-the-counter (OTC) derivative markets throughout the EU states. It is designated Regulation (EU) 648/2012, and it entered into force on 16 August 2012.

Note 13. Committee of European Securities Regulators

Note 14. Bank for International Settlements, Basle. 